University for Business and Technology in Kosovo

UBT Knowledge Center

UBT International Conference

2018 UBT International Conference

Oct 27th, 9:00 AM - 10:30 AM

\title{
Modeling the effect of temperature on rheological properties of red wine
}

\author{
Anisa Dhroso \\ University of Tirana, anisa.dhroso@fshn.edu.al \\ Hasime Manaj \\ University of Tirana \\ Ilirjan Malollari \\ University of Tirana \\ Berisha Varvara \\ University of Tirana
}

Follow this and additional works at: https://knowledgecenter.ubt-uni.net/conference

Part of the Food Science Commons

\section{Recommended Citation}

Dhroso, Anisa; Manaj, Hasime; Malollari, llirjan; and Varvara, Berisha, "Modeling the effect of temperature on rheological properties of red wine" (2018). UBT International Conference. 179.

https://knowledgecenter.ubt-uni.net/conference/2018/all-events/179

This Event is brought to you for free and open access by the Publication and Journals at UBT Knowledge Center. It has been accepted for inclusion in UBT International Conference by an authorized administrator of UBT Knowledge Center. For more information, please contact knowledge.center@ubt-uni.net. 


\title{
Modeling the effect of temperature on rheological properties of red wine
}

\author{
Anisa Dhroso ${ }^{1}$, Ilirjan Malollari ${ }^{1}$, Hasime Manaj ${ }^{1}$, Varvara Berisha ${ }^{1}$ \\ ${ }^{1}$ Department of Industrial Chemistry, Faculty of Natural Sciences, \\ University of Tirana, Tirana, Albania \\ e-mail: anisa.dhroso@fshn.edu.al
}

\begin{abstract}
Wine is an alcoholic beverage produced through the partial or total fermentation of grapes. Wine is characterized by color: white, pink or rose, and red. Red wine available in Albanian market was characterized for physicochemical and rheological properties. In the first phase, the physicochemical parameters were determined: density, total acidity, volatile acids, content of the alcohol, reduced sugars, free $\mathrm{SO}_{2}$, total $\mathrm{SO}_{2}, \mathrm{pH}$ and electric conductivity. In the second phase of the study, density and dynamic viscosity were experimentally determined as a function of temperature from 5 to $40^{\circ} \mathrm{C}$. Kinematic viscosity and fluidity were determined according to the definitions. The dynamic viscosity of wine was represented as a function of temperature by using two and multi-constant proposed mathematical models.
\end{abstract}

Keywords: red wine, temperature, density, rheological properties.

\section{Introduction}

Grapevine is the most commonly grown kind of fruit worldwide. Currently, the area of vineyards is about 8 million hectares. In Europe, it occupies approximately $57 \%$ of the hectareage ie about 4.5 million hectares [19]. Albania has one of Europe's longest histories of viticulture. The country has one of the oldest wine making traditions, dating back to the ice and Bronze Age whereas Ancient Illyrians and Greeks inhabited the country's territory some 3,000 years ago. It belongs chronologically to the old world of wine producing countries. The ancient Roman writer Elder described Illyrian wine as being very sweet or luscious and refers to it as taking the third rank among all the wines [12]. The Albanian wine is produced in several regions throughout Albania within the Mediterranean Basin. Albania is a mountains Mediterranean country and extends within the Mediterranean Basin with the Mediterranean Sea in the west. The country experiences a distinctly Mediterranean climate, which means that the winters are mild and summers usually hot and dry [11]. Albania can be separated into four wine regions, which are mainly defined by their altitude. (1) The coastal plain (Western lowland) rises to 300 $\mathrm{m} / 990 \mathrm{ft}$ and encompasses the towns of Tirana, Durresi, Shkodra, Lezha, Lushnja, Fier, 
Vlora, and Delvina. (2) The central hilly region varies between 300 and $600 \mathrm{~m} / 1,980 \mathrm{ft}$ altitude and includes Elbasan, Kruje, Gramsh, Berat, Permet, Librazhd, and Mirdita. (3) The Eastern sub-mountainous region lies between 600 and $800 \mathrm{~m}$ and surrounds the towns of Pogradec, Korca, Leskovic, and Peshkopi. (4) Mountains (Highlands) vines are also grown as high as $1,000 \mathrm{~m}$. Soils are generally clay silica of varied depths and exposures [15]. The favourable climate and fertile soil of the mountainous areas of the country are well suited to viticulture. The wine production is associated mainly with countries of moderate climate with long, hot summers. However, the vineyards are located also in countries of cooler climate [18]. Albania produced an estimated 17,500 tonnes of wine in 2014. Wine is an alcoholic beverage made from partial or total fermented grapes or other fruits. Wines may be classified by vinification methods. Red wine is made from red (or black) grapes, but its red color is bestowed by a process called maceration, whereby the skin is left in contact with the juice during fermentation $[4,16]$. Fermentation processes are done by the yeast Saccharomyces, whereby the sugars in the fruit juice are metabolised into alcohol and $\mathrm{CO}_{2}$, that later react to form organic acid, aldehydes, esters and other chemical components [2,9]. For the quality evaluation of food materials, it is important to know their physical properties particularly, mechanical, rheological, and thermo physical [10]. In this article, the results of measurement of physicochemical and rheological parameters are presented for a sample of red wine. The dynamic viscosity of wine was experimentally determined as a function of temperature $\left(5\right.$ to $\left.40^{\circ} \mathrm{C}\right)$. The variation of the viscosity of red wine with the temperature is analyzed applying the two and multi constant equations.

\section{Material and method}

Red wine available in Albanian market was characterized for physicochemical and rheological properties. For this purpose we choose the red wine from western lowland, because this is one of the main grape growing regions. In the first phase, the physicochemical parameters were determined: density, total acidity, volatile acids, content of the alcohol, reduced sugars, free $\mathrm{SO}_{2}$, total $\mathrm{SO}_{2}, \mathrm{pH}$ and electric conductivity following the analytical methods described in Albanian Standard [5]. In the second phase of the study, density and dynamic viscosity were experimentally determined as a function of temperature from 5 to $40^{\circ} \mathrm{C}$. All measurements were performed in three repetitions. For the determination of the density, the pycnometric method was used. For this purpose, pycnometers with a volume of $50 \mathrm{ml}$ and an analytical balance with an accuracy of 0.0001 $\mathrm{g}$ were used. The content of alcohol in wine was determined by SSH 1446-1:1987 method. The concentration of reduced sugars was determined with Fehling method (SSH 1446-2:1987). For the determination of total acidity, a analytical method was used (SSH 1446-3:1987). All titrated acids in the wine are the sum of compounds titratable by standard alkaline solution to $\mathrm{pH}$ 7. Carbonic acid is not included in total acidity. The free acidity, was determined according to $\mathrm{SSH}$ 1446-4:1987. Free and total $\mathrm{SO}_{2}$ was determined by titration of the standard solution of iodine (SSH 1446-7:1987 and SSH 1446-6:1987). The $\mathrm{pH}$ measurement of red wine was obtained with a $\mathrm{pH}$ meter (PHS- 
3CW Microprocessor $\mathrm{pH}$ Meter) was calibrated with standard solutions buffered. Also we measured the electric conductivity with DDS-120W Microprocessor Conductivity Meter. Viscosity and temperature of red wine samples were measured using the Digital Viscometer Model NDJ-5S with accuracy $\pm 1 \%$. The SP-0 spindle was operated at $60 \mathrm{rpm}$. The Electric model L-81 was used to increase the temperature of the wine samples to a specific temperature. Kinematic viscosity and fluidity were determined according to the definitions. Office Excel 2016 software was used to carry out the effect of temperature on dynamic viscosity of red wine by different mathematical models. Where, the dynamic viscosity of wine was represented as a function of temperature by using two and multiconstant proposed mathematical models. Equation 1, include the Arrhenius model that is commonly used to model temperature dependence of a property [3].

$$
\mu=\mu_{\infty, T} \exp \left(\frac{E_{a}}{R T}\right)
$$

Where $\mu$ is the dynamic viscosity in mPa.s, $\mu_{\infty, \mathrm{T}}$ is the viscosity at infinite-temperature in $\mathrm{mPa} . \mathrm{s}, \mathrm{E}_{\mathrm{a}}$ is the exponential constant that is known as activation energy $(\mathrm{J} / \mathrm{mol}) ; \mathrm{R}$ is the gas constant $(\mathrm{J} / \mathrm{mol} . \mathrm{K})$ and $\mathrm{T}$ is the absolute temperature Kelvin. Multi-constant formula known as Andrade (three constant) and Clements (four constant) models that are represented in the following equations $[1,3]$ :

$$
\operatorname{Ln} \mu=A+\frac{B}{T}+\frac{C}{T^{2}} \quad \text { and } \quad \operatorname{Ln} \mu=A+\frac{B}{T}+\frac{C}{T^{2}}+\frac{C}{T^{3}}
$$

Where $\mu$ is the dynamic viscosity in mPa.s, T is the temperature in Kelvin. A, B and C are constants. Kinematic viscosity $\left(\mathrm{m}^{2} \cdot \mathrm{s}^{-1}\right)$ is defined as a ratio of dynamic viscosity to density of fluid $\rho\left(\mathrm{kg} \cdot \mathrm{m}^{-3}\right)$ at the same temperature.

$$
\eta=\frac{\mu}{\rho}
$$

Reciprocal value of dynamic viscosity is called fluidity $\varphi$ and unit of fluidity is $\mathrm{mPa}^{-1} \cdot \mathrm{s}^{-1}$ [6].

$$
\varphi=\frac{1}{\mu}
$$

The mean absolute percentage error (MAPE), which indicates the deviance of the observed values from the calculated, was calculated using the following formula:

$$
M_{A P E^{a}}=\frac{\left|\sum_{1=1}^{n}\left(\frac{A_{0}-A_{C}}{A_{0}}\right)\right|}{n} \cdot 100
$$

Where $\mathrm{A}_{0}$ is the observed value, $\mathrm{A}_{\mathrm{C}}$ is the calculated value, and $n$ represents the number of pairs of samples. 


\section{Results and discussion}

The red wine quality and behavior can be influenced by the plant's environment, species and varieties, viticulture and enological practices [20]. Several physicochemical and rheological characteristics of red wine were investigated. The limit values of physicochemical and rheological parameters in wine available on the market must comply with the national law of the Albanian Republic and the European Union law. By comparing our experimental data with standard value, we can see that they are roughly the same, with very little difference. This may come as a result of many factors that affect the quality of the wine and therefore the experimental results. Ethyl alcohol is the predominant constituent of alcoholic fermentation. The yield of alcohol mainly depends on the initial sugar content of the juice [8]. The content of alcohol in wine is affected by many factors, such as ripeness of the grapes at the time of harvest, grape processing technology, and fermentation technology [9]. The red wine had $11 \%$ vol. alcohol content. According to the grams per liter residual sugar in a wine, can determined the product type: dry, medium dry, medium sweet and sweet. In accordance with Europe wine regulations is not higher than $4 \mathrm{~g} / \mathrm{l}$, so red wine can be classified into the category of dry wines. The analyzed sample had $2.5 \%$ residual sugar. $\mathrm{pH}$ and electric conductivity of red wine sample were 3.49 and $2.19 \mathrm{mS}$, at $20^{\circ} \mathrm{C}$, respectively. Typical $\mathrm{pH}$ levels in wine normally range from 3 to 4 and can be measured using a $\mathrm{pH}$ meter [7]. Care should be taken during $\mathrm{pH}$ measurement to ensure accurate results as there are various components in juice and wine that can affect the performance of the $\mathrm{pH}$ electrode; these include proteins, sulfides, tannins, and polyphenols. Wine contains mainly organic acids like tartaric, malic and citric acids. Acidity plays a crucial role in imparting taste and flavour to the wine besides protecting the wine from spoilage [17]. The acids are important in maintaining $\mathrm{pH}$ low enough to inhibit the growth of many undesirable bacteria, thus giving advantage to wine yeasts [8]. A total acidity and flurry acidity of red wine were $5.4 \mathrm{~g} / \mathrm{l}$ and $0.624 \mathrm{~g} / \mathrm{l}$, respectively. According to Ribéreau and Traduction, report that the content of acids in wine ranges between 5 and $7.5 \mathrm{~g} \mathrm{l}^{-1}$ [14]. There is a relation between the value of $\mathrm{pH}$ and acids contained in wine. When the content of acids is higher, the $\mathrm{pH}$ value is lower [13]. Sulfur dioxide $\left(\mathrm{SO}_{2}\right)$ is widely used in wine production as a chemical antioxidant and inhibitor of microbial activity. There are a number of traditional methods for determining free and total $\mathrm{SO}_{2}$ in wine involving distillation or iodometric titration. The total and free amount of sulphur dioxide in wine, were $144 \mathrm{mg} / \mathrm{l}$ and $16 \mathrm{mg} / \mathrm{l}$, respectively. Red wines have maximum allowed limit $160 \mathrm{mg} \mathrm{l}^{-1}$. None of the evaluated samples exceeded the maximum allowable limit. Density of red wine at different temperatures ranges of 1.0020 to $0.9925 \mathrm{~g} / \mathrm{cm}^{3}$. The experimental dates of red wine versus temperature are presented in Figure 1. 

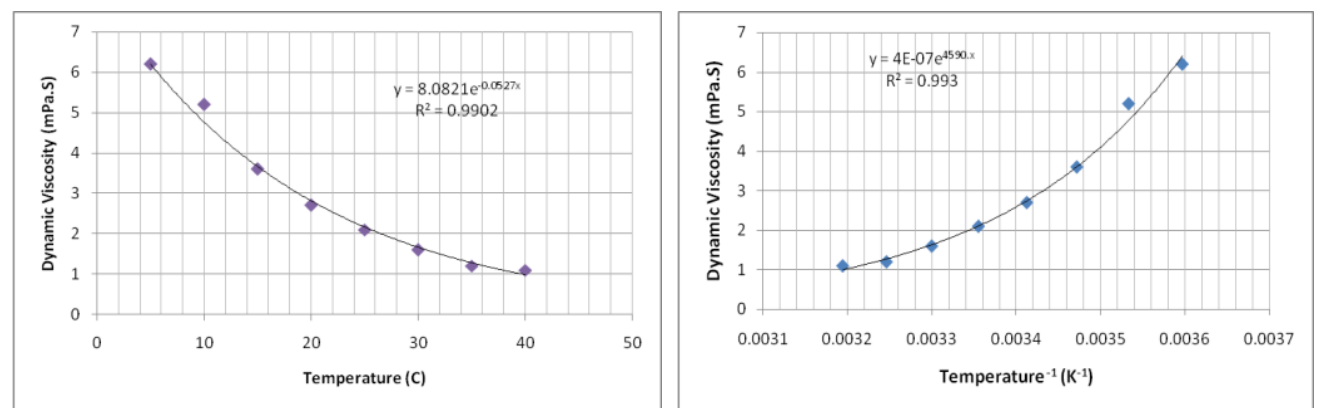

(a)

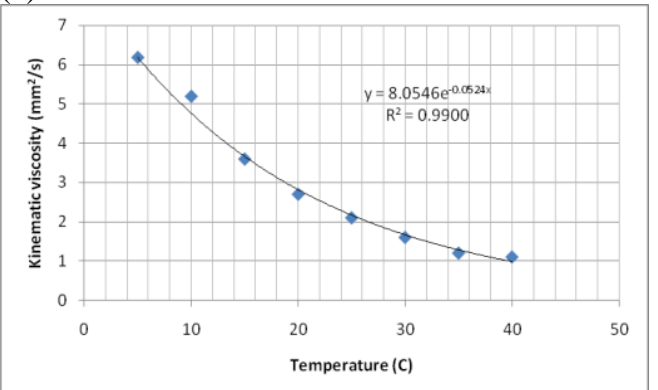

(d)

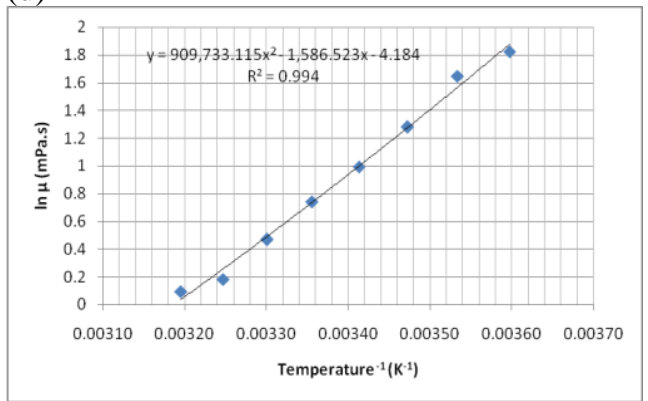

(b)

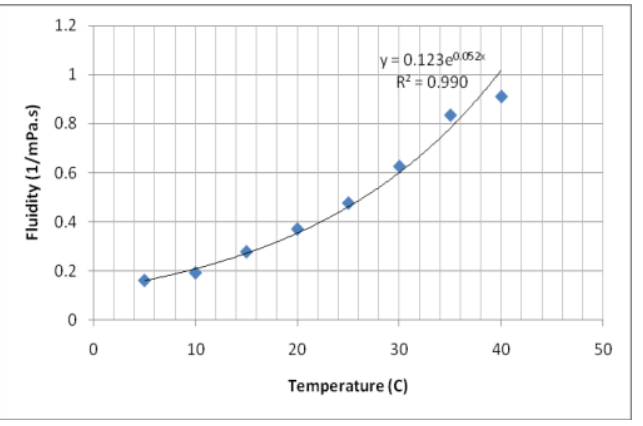

(f)

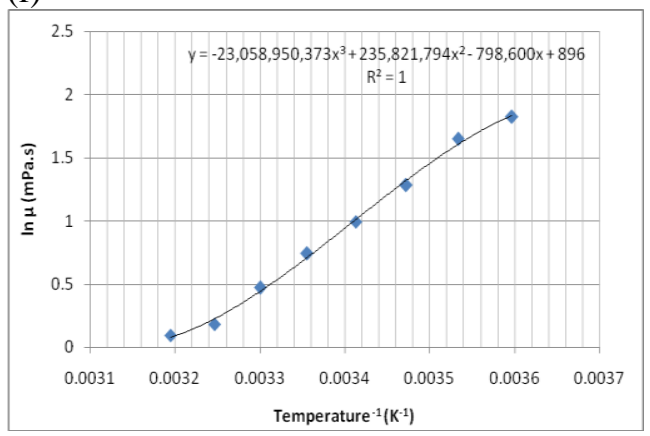

(c)

(e)

Fig. 1. Effect of temperature on (a) density, (b) dynamic viscosity, (c) kinematic viscosity, (d) Arrhenius model, (f) Andrade model and (e) Clements model of red wine

The experimental data of red wine, for dynamic viscosity (mPa.s) versus temperature is shown in Fig. 1 (a). The dynamic viscosity of red wine is decreasing with increasing of temperature. The kinematic viscosity can be calculated from the dynamic viscosity and the density (equation 3). On Fig. 1 (b) is presented kinematic viscosity decreasing versus temperature range $5-40^{\circ} \mathrm{C}$. While fluidity is increasing with increasing of the temperature, is presented in Fig. 1 (c). The values of the estimated constants and 
correlation coefficients are shown in each equation, set in the graphs. The experimental data of red wine, for dynamic viscosity fitting by Arrhenius, Andrade and Clements models are presented in Fig. 1 (d-e), by using Equation 1 and 2 respectively. According to, the Arrhenius model results, the value of activation energy of the analyzed red wine was $38.1 \mathrm{~kJ} / \mathrm{mol}$, which describe the sensitivity of viscosity to temperature changes. The values of the estimated constants are shown in each equation, set in the graphs. In all cases the determination coefficient $\left(R^{2}\right)$ exceeded values >0.99: 0.993 Arrhenius model, 0.994 Andrade model and 1 Clements model. The mean absolute percentage errors (MAPE ${ }^{a}$ ) were below 10\%: 7.57\% Arrhenius model, 2.27\% Andrade model and 0.53\% Clements model. All of the mean absolute percentage errors were low, which means that the viscosity values obtained were very stable. However, comparisons of the calculated data indicate that the temperature-dependence of viscosity for the red wine sample was best described by the Clements model. An equation with lower MAPE values gives a better fit to experimental data compared to an equation with higher MAPE values.

\section{Conclusions}

The article is focused in physicochemical parameters determination and on influence of temperature on rheological parameters of red wine made in Albania. The physicochemical parameters results depend on red wine nature and can be used as a way of characterizing the wine quality. The limit values of physicochemical and rheological parameters in wine were within the Albanian and European standard values. The dynamic viscosity versus temperature of wine was measured and described by different mathematical models. The value of correlation coefficient and mean absolute percentage error indicates that the models fit satisfactorily to experimental data. However, comparisons of the results obtained indicate that the temperature dependence of viscosity for the red wine sample was best described by the Clements model.

\section{References}

1. Abramovic H., Klofutar G.: "The temperature dependence of dynamic viscosity for some vegetables oils ", Acta Chim. Slov. 45(1), (1998), 69-77.

2. Clarke O.: Encyclopedia of Grapes pg 129-133 Harcourt Books ISBN 0-15-100714-4, (2001).

3. Clements L. D., Noureddini H. and Teoh B. C.: "Viscosity of vegetables oils and fatty acids ", J. Am. Oil Chem. Soc., 69 (12), (1992), 1189-1191.

4. Boulton, B., Singleton, V.L., Bisson, L.F. and Kunkee, R.E., Principles and practices of winemaking. New York: Chapman and Hall, (1996).

5. General Directorate of Standardization Albania, SSH 1446:1987; (2017).

6. Hlaváč P., Božiková M., Hlavačova1 Z., Kubik L.: Influence of temperature and storing time on selected red wine physical properties, Acta Universitatis Agriculturae et Silviculturae mendelianae brunensis, volume 64, number 2, (2016), pg 433-439.

7. Jacobson J.L.: Introduction to Wine Laboratory Practices and Procedures. New York: Springer Science, New York, USA. (2006). 
8. Joshi V., Rao b. S., Reddy R. S.: Studies on the physico-chemical properties on wine in different varieties of grapes, The asian journal of horticulture Volume 8 | Issue 1, June, (2013), 174-178.

9. Kaltzin W.: Natural wines als Trend. Der Winzer, 10(4), (2012), 85-87.

10. Manzocco L., Maltini E., Lerici C.R.: Changes of some thermal and physical properties in model system simulating an alcoholic fermentation. Journal of Food Processing and Preservation, 22: 1-12, (1998).

11. Ministry of Environment of Albania.: "Albania's Second National Communication to the Conference of Parties under the United Nations Framework Convention on Climate Change" (PDF). Unfccc.int. Tirana, (2009) p. 28.

12. Patton W.: The Laws of Fermentation and the Wines of the Ancients, Bronson Press. p. 41. Retrieved 2011-04-10, (2010).

13. Ribéreau-Gayon P. and Branco J.M.: Handbook of enology. West Sussex: John Wiley Sons, West Sussex, England, (2006).

14. Ribéreau-Gayon P. and Traduction A.: Handbook of enology: The chemistry of wine stabilization and treatments. West Sussex, England, (2003).

15. Robinson J.: Jancis Robinson's Wine Course Third Edition Abbeville Press 2003 ISBN 0-78920883-0, (2003), pg 142-143.

16. Robinson J. ed: Oxford Companion to Wine. Oxford: Oxford University Press. 2015. p. 10. ISBN 9780198705383, (2015).

17. Sim, C.A. and Morris, J.R.: Effect of $\mathrm{pH}, \mathrm{SO} 2$, storage time and temperature on the colour and stability of red muscadine grape wine. Amer. J. Enol.Vitic., (1984), 35(1): 35-39.

18. Tarko T., Duda-Chodak A., Sroka P., Satora P., Jurasz E., Physicochemical and antioxidant properties of selected polish grape and fruit wines, Acta Sci. Pol., Technol. Aliment. 7(3), (2008), 35-45.

19. Trávníček P., Burg P., Krakowiak-Bal A., Junga P., Vítěz T.,and Ziemiańczyk U., Study of rheological behaviour of wines, Int. Agrophys., (2016), 30, 509-518.

20. Torres B.: 4 factors that determine wine quality, (2015), www.torres.es 